\title{
Evaluation Forage Clipping Stages and Different Levels of Nitrogen on Grain and Forage Yields of TRITICALE $(\times$ TRITICOSECALE WITTMACK)
}

\author{
Mohsen Niazkhani1 ${ }^{1}$ Abdolmajid Khorshid ${ }^{2}$, Alireza Eivazi ${ }^{2}$ \\ ${ }^{1}$ Department of Plant Breeding, Zanjan University, Zanjan, Iran \\ ${ }^{2}$ Agricultural Research Center of West Azerbaijan Province, Urmia, Iran \\ Email: mohsen.n114@gmail.com, ab khorshidy@yahoo.com, alirezaeivazi@yahoo.com
}

Received 4 May 2014; revised 3 June 2014; accepted 20 June 2014

Copyright (C) 2014 by authors and Scientific Research Publishing Inc.

This work is licensed under the Creative Commons Attribution International License (CC BY). http://creativecommons.org/licenses/by/4.0/

\section{(c) (i) Open Access}

\begin{abstract}
In order to reach suitable forage clipping and estimate nitrogen fertilizer to most economical proficiency, an experiment was carried out at Saatlo Station in 2008-2009 seasons. A factorial experiment was done based on the randomized complete blocks design with 4 replications. The first factor was three levels of clipping stages including non-clipping, clipping at tillering and booting stages. Different levels of nitrogen fertilizer including $0,40,80,120$ and $160 \mathrm{~kg} / \mathrm{ha}$ were arranged at the second factor. Results showed that non-clipping and clipping at booting stage with 610.5 and $203.1 \mathrm{~g} / \mathrm{m}^{2}$ had the most and the lowest grain yield, respectively. The highest economical proficiency (3743.06 \$/ha) resulted with using $80 \mathrm{~kg} / \mathrm{ha}$ nitrogen fertilizer and non-clipping. With considering both forage and grain yield, it is necessary that the clipping should be done at tillering stage with using of $120 \mathrm{~kg} / \mathrm{ha}$ nitrogen fertilizer (3336.56 \$/ha). At regression of economical proficiency traits of grain yield, straw and total dry matter remained at the final model. Economical proficiency had the significant positive correlation with spike per square meter $\left(0.87^{* *}\right)$, grain yield $\left(0.64^{* *}\right)$, total dry matter $\left(0.65^{* *}\right)$, plant height $\left(0.52^{* *}\right)$ and 1000 -kernal weight $\left(0.54^{* *}\right)$.
\end{abstract}

\section{Keywords}

Forage Yield, Grain Yield, Triticale

\section{Introduction}

The significant percentage of the population's food is dependent on agriculture. Forage supplies are associated

How to cite this paper: Niazkhani, M., Khorshid, A. and Eivazi, A. (2014) Evaluation Forage Clipping Stages and Different Levels of Nitrogen on Grain and Forage Yields of TRITICALE (× TRITICOSECALE WITTMACK). American Journal of Plant Sciences, 5, 2199-2206. http://dx.doi.org/10.4236/ajps.2014.515233 
with livestock sector and play a very large share on the protein production. In addition to agricultural sector, one of the largest sources of forage is renewable resources, particularly rangelands. Natural resources in Iran included more than $83.5 \%$ of the country's area (135.4 million hectares). The area (86.1 million hectares of this amount) is rangelands that are able to supply food for 40 million animal units [1]. Overgrazing can degrade of rangelands and reduce the livestock, production dairy products and protein.

Grazing cereal fields or harvesting green fodder to provide the food for livestock usual in many parts of the world, such as countries in West Asia, North Africa, Australia, England, New Zealand, and also in Iran. In Oklahoma 1.5 million hectares of wheat fields are grazed the annual [2]. The goals of the dual-purpose sowing are providing livestock forage needed in food shortage time on one hand, and on the other hand reaching proper functioning grain after harvested green fodder. Triticale is very flexible so can be used it in order to graze, comminuted green forage, dry forage, silage or grain [3]. Some of triticale cultivars have a very high nutritional value and can be accelerated weight gain of livestock. Nutritional value of triticale is higher than other cereal crops [4]. Dual culture would be economically, if the forage and grain economic values are greater than grains harvested [5]. Access to green forage with palatability and high quality product is the dual purpose goal for subsequent planting. In this regard, there are some reports about the high quality protein derived from green forage crops in the early stages of growth [6]. The aim of this study was to evaluate the different clipping stages of forage and amounts of nitrogen fertilizer application on grain and forage yield and estimated economic value of triticale for growing under conditions of Urmia.

\section{Material and Methods}

Experimental location: An experiment was carried out under field conditions at Saatloo station of agricultural research center of west Azerbaijan province Urmia, Iran in 2008-2009 seasons. The site located in latitude $37^{\circ} 44^{\prime} 18^{\prime \prime} \mathrm{N}$, longitude $45^{\circ} 10^{\prime} 53^{\prime \prime} \mathrm{E}$ and $1338 \mathrm{~m}$ altitude. Mean temperature and annual precipitations were $9.25^{\circ} \mathrm{C}$ and $160 \mathrm{~mm}$, respectively (Table 1 and Table 2).

Table 1. Soil physico-chemical properties of Saatloo agricultural research station from 0 - $35 \mathrm{~cm}$ depth.

\begin{tabular}{|c|c|c|c|c|c|c|c|}
\hline $\begin{array}{c}\text { Available } \\
\text { potassium } \\
\text { (ppm) }\end{array}$ & $\begin{array}{c}\text { Available } \\
\text { phosphorus } \\
\text { (ppm) }\end{array}$ & $\begin{array}{c}\text { Total nitrogen } \\
\text { (\%) }\end{array}$ & $\begin{array}{c}\text { Organic carbon } \\
(\%)\end{array}$ & Soil texture & $\begin{array}{c}\text { Soil saturation } \\
\text { (\%) }\end{array}$ & Acidity & $\begin{array}{c}\text { Salinity acidity } \\
(\mathrm{ds} / \mathrm{m})\end{array}$ \\
\hline 425 & 12 & 0.12 & 1.2 & Clay loam & 47 & 8 & 0.8 \\
\hline
\end{tabular}

Table 2. Meteorological parameters of Satloo agricultural research station in 2010-2011 seasons.

\begin{tabular}{|c|c|c|c|c|c|}
\hline Month & $\begin{array}{l}\text { Precipitation } \\
\quad(\mathrm{mm})\end{array}$ & $\begin{array}{c}\text { Relative humidity } \\
\text { (\%) }\end{array}$ & $\begin{array}{l}\text { Minimum absolute } \\
\text { temperature }\left({ }^{\circ} \mathrm{C}\right)\end{array}$ & $\begin{array}{l}\text { Minimum temperature of } \\
\text { soil surface }\left({ }^{\circ} \mathrm{C}\right)\end{array}$ & Frost days \\
\hline October & 1.2 & 75.0 & 7.2 & 3.3 & 1 \\
\hline November & 7.6 & 82.1 & 2.6 & -1.9 & 10 \\
\hline December & 30.4 & 92.5 & -3.3 & -6.6 & 25 \\
\hline January & 8.0 & 92.5 & -10.8 & -15.6 & 30 \\
\hline February & 51.5 & 92 & -15.4 & -14 & 29 \\
\hline March & 25.2 & 80.8 & -1.0 & -4.6 & 19 \\
\hline April & 3.4 & 72.3 & 4.7 & 0.9 & 1 \\
\hline May & 24.5 & 74.1 & 7.6 & 3.9 & 0 \\
\hline June & 0 & 71.5 & 11.5 & 7.7 & 0 \\
\hline July & 10.9 & 71.1 & 15.6 & 13.1 & 0 \\
\hline
\end{tabular}


Execution of trial: In order to evaluate different stages of harvesting and application levels of nitrogen fertilizer on Jualino-92 triticale cultivar a factorial experiment based on randomized complete blocks design with four replications was carried out. Three forage harvesting stages including tiller, booting and non-harvesting arranged at first factor. Five application levels of nitrogen fertilizers with 0, 40, 80, 120 and $160 \mathrm{~kg} / \mathrm{ha}$ were second factor.

Agronomical practices: Field preparation and performing design was done in autumn 2008. 15 plots arranged at each block and total plots were 60. Each plot had six rows with three meter length and between row $20 \mathrm{~cm}$. After sowing with 400 grains $/ \mathrm{m}^{2}$ density plots were irrigated. At the growing season weed removed mechanically and irrigation were done five times with 15 days intervals. Forage harvested from each plot at early April and Middle May coincident with tiller and booting stages. At physiological maturity after removing border rows plants of each plots were separately harvested and grain yield and straw weighed. Samples of straw were used for measuring cured protein with Microkejeldal set and ash with electrical oven.

Measurement of traits: From each plot ten plants were randomly selected for measuring plant height, number of grains at per plants and spike weight. Number of spike per square meter recorded from middle rows.

After harvesting 250 grains accounted from each plot and weighted for measuring 1000-kernel weight. Forage yield of each plot measured at tillering, booting stages [7]. Economical proficiency counted for field preparation (plow and disk) sowing (seed providing, disinfection, application of potassium and phosphate fertilizers), agronomical practice (excess fertilizer, weed, pests and diseases chemically control, irrigation) harvesting (moving, collection, transportation) field rent price, crop insurance and profit found (Table 3).

Data were analyzed with Mstat-C and SPSS software 13 version. Means compared with multiple Duncan's range test at 0.05 probability level.

\section{Results and Discussion}

Results analysis of variance showed that forage clipping stages were significant differences at all traits $(\mathrm{p} \leq 0.01)$ (Table 4). Different levels of nitrogen fertilizer were significant differences for traits of organic matter and

Table 3. Input and output prices of triticale in 2012-2013.

\begin{tabular}{cccc}
\hline Input & Price (US \$/ha) & Output & Price (US \$/kg) \\
\hline Field preparation & 57.500 & Grain & 0.312 \\
Sowing & 102.17 & Straw & 0.208 \\
Agronomical practices & 165.21 & Dry forage harvested at tillering stage & 0.521 \\
Harvest & 81.375 & Dry forage harvested at booting stage & 0.417 \\
Etc. & 236.687 & & \\
\hline
\end{tabular}

Net profit = (approximate price of product*amount of product $)-$ costs.

Table 4. Mean square traits of triticale under field conditions during 2008-2009 seasons.

\begin{tabular}{|c|c|c|c|c|c|c|c|c|c|c|c|}
\hline \multirow{2}{*}{ Source of variance } & \multicolumn{11}{|c|}{ Mean squares } \\
\hline & $\mathrm{df}$ & $\mathrm{PH}$ & $\mathrm{S} / \mathrm{m}^{2}$ & GS & KW & GY & TDM & HI & OMF & $\mathrm{CPF}$ & EP \\
\hline Replication & 3 & 205.0 & 54870.6 & 207.1 & 34.5 & 1029.6 & 84985.6 & 0.03 & 1.8 & 3.9 & 90782.9 \\
\hline Clipping stage & 2 & $476.0^{* *}$ & $77943.5^{* *}$ & $446.4^{* *}$ & $97.8^{* *}$ & $927790.6^{* *}$ & $1543911.2^{* *}$ & $0.23^{* * *}$ & $142.1^{* *}$ & $1271.2^{* *}$ & $5752072.8^{* *}$ \\
\hline Nitrogen level & 4 & $31.8^{\mathrm{ns}}$ & $18642.8^{*}$ & $66.4^{\mathrm{ns}}$ & $19.9^{\mathrm{ns}}$ & $3528.9^{\mathrm{ns}}$ & $46401.1^{\mathrm{ns}}$ & $0.003^{\mathrm{ns}}$ & $6.8^{* *}$ & $12.0^{* *}$ & $95936.2^{\mathrm{ns}}$ \\
\hline Clipping $\times$ nitrogen & 8 & $51.1^{\mathrm{ns}}$ & $3994.8^{\mathrm{ns}}$ & $204.3^{* *}$ & $27.0^{\mathrm{ns}}$ & $5423728^{\mathrm{ns}}$ & $63713.4^{\mathrm{ns}}$ & $0.002^{\mathrm{ns}}$ & $4.7^{* *}$ & $11.3^{* *}$ & $172470.9^{*}$ \\
\hline Error & 42 & 42.1 & 7103.0 & 45.5 & 29.9 & 3885.6 & 36190.1 & 0.002 & 0.1 & 4.2 & 70521.5 \\
\hline \multicolumn{2}{|c|}{ Coefficient of variation (\%) } & 6.8 & 20.1 & 13.6 & 11.5 & 13.9 & 13.7 & 14.6 & 10.4 & 8.2 & 14.7 \\
\hline
\end{tabular}

ns ${ }^{*}$ and ${ }^{* *}$ : was not significant and significant at 0.05 and 0.01 probability levels, respectively. PH: plant height, GS: grain per spike, S/m²: spike per square meter, GY: grain yield, KW: 1000-kernel weight, TDM: total dry matter, HI: harvest index, EP: economical proficiency, OMF: organic matter of forage, CPF: crude protein of forage. 
crude protein of forage $(\mathrm{p} \leq 0.01)$ and number of spike per square meter $(\mathrm{p} \leq 0.05)$. Also, interactions between them for traits of grain per spike, organic matter and crude protein forage $(\mathrm{p} \leq 0.01)$ and economical proficiency $(\mathrm{p} \leq 0.05)$ were significant.

Grain yield and its components: Non-clipping $\left(610 \mathrm{~g} / \mathrm{m}^{2}\right)$ and clipping at booting stage $\left(203 \mathrm{~g} / \mathrm{m}^{2}\right)$ had the most and lowest grain yield, respectively (Table 5). Delay of clipping at growing season reduce cereal grain yield [8]. It is due to reduction of leaf area, photosynthetic rate and consequently decreases in 1000-kernel weight and spike per square meter [9].

Highest number of spike achieved at tiller clipping stage with 511 spikes per square meter and lowest amount reached at booting clipping stage with 323 spikes per square meter (Table 5). Forage clipping increased number of spike per square meter. Delay of harvesting time due to short growing season reduced opportunity re-growth resulted reduction of effective tillers.

At non-application and application of $80 \mathrm{~kg} / \mathrm{ha}$ nitrogen fertilizer with 456 and 449 spike per square meter had the highest. In contrast application of $160 \mathrm{~kg}$ /ha with 356 spike per square meter had the lowest value (Table 6). Clipping induced vegetative meristem growth and then increased number of tillers. Triticale in cereal family has the highest ability of tiller production. High forage yield can be achieved with clipping at the tiller stage.

Grain per spike depends on number of fertile spikelet at per spike [7]. Non-clipping and $40 \mathrm{~kg} / \mathrm{ha}$ nitrogen fertilizer application with 60 grain per spike had the most value. In opposite, clipping at tiller stage with 40 $\mathrm{kg} / \mathrm{ha}$ nitrogen fertilizer and clipping at booting stage with non application nitrogen fertilizer with 40 and 41 grain per spike had the lowest values (Table 7).

The gross kernels were allocated for non-clipping and clipping at tiller stage with 51 and $48 \mathrm{~g}$. In opposite, the lowest 1000-kernel weight belonged to clipping at booting stage with $39 \mathrm{~g}$. 1000-kernel weight is influenced by photosynthesis at grain filling period. With decreasing leaf area and photosynthesis rate 1000-kernel weight is reduced. Grain weight loss due to heavy grazing also has been reported by various researchers [10]. Grains act as a source of assimilates and at early growth stages have chlorophyll and are effective in hydrocarbon production [11]. Non-clipping and clipping at booting stage with 38\% and $18 \%$ had the highest and lowest harvest index, respectively. Having higher harvest index was due to more grain per spike [12].

Forage yield and related trait: Non-clipping and clipping at tiller stage with more than $1472 \mathrm{~g} / \mathrm{m}^{2}$ and clip-

Table 5. Mean comparison triticale traits at different clipping stages.

\begin{tabular}{|c|c|c|c|c|c|c|}
\hline Clipping stage & $\mathrm{PH}(\mathrm{cm})$ & $\mathrm{S} / \mathrm{m}^{2}$ & KW (g) & $\mathrm{GY}\left(\mathrm{g} / \mathrm{m}^{2}\right)$ & $\mathrm{TDM}\left(\mathrm{g} / \mathrm{m}^{2}\right)$ & HI (\%) \\
\hline Non-clipping & $110^{\mathrm{a}}$ & $421^{\mathrm{b}}$ & $51^{\mathrm{a}}$ & $610^{\mathrm{a}}$ & $1604^{\mathrm{a}}$ & $38^{\mathrm{a}}$ \\
\hline Tiller stage & $99^{b}$ & $511^{\mathrm{a}}$ & $48^{\mathrm{a}}$ & $527^{\mathrm{b}}$ & $1472^{\mathrm{a}}$ & $35^{b}$ \\
\hline Booting stage & $75^{c}$ & $323^{\mathrm{c}}$ & $39^{\mathrm{b}}$ & $203^{\mathrm{c}}$ & $1070^{\mathrm{b}}$ & $18^{\mathrm{c}}$ \\
\hline
\end{tabular}

Means within the same letter(s) at each column were not significant differences at 0.05 probability level. PH: plant height, S/m²: spike per square meter, GY: grain yield, KW: 1000-kernel weight, TDM: total dry matter, HI: harvest index.

Table 6. Mean comparison triticale traits at different nitrogen applications.

\begin{tabular}{ccccccc}
\hline \multirow{2}{*}{$\begin{array}{c}\text { Different nitrogen } \\
\text { applications }\end{array}$} & $\mathrm{PH}(\mathrm{cm})$ & $\mathrm{S} / \mathrm{m}^{2}$ & $\mathrm{KW}(\mathrm{gr})$ & $\mathrm{GY}\left(\mathrm{gr} / \mathrm{m}^{2}\right)$ & $\mathrm{TDM}\left(\mathrm{gr} / \mathrm{m}^{2}\right)$ & $\mathrm{HI}(\%)$ \\
\hline Control & $93.2^{\mathrm{a}}$ & $456.5^{\mathrm{a}}$ & $47.2^{\mathrm{a}}$ & $447.4^{\mathrm{a}}$ & $1401.1^{\mathrm{a}}$ & $0.297^{\mathrm{a}}$ \\
$40 \mathrm{~kg}$ & $94^{\mathrm{a}}$ & $413.4^{\mathrm{ab}}$ & $48.5^{\mathrm{a}}$ & $423.4^{\mathrm{a}}$ & $1332.6^{\mathrm{a}}$ & $0.299^{\mathrm{a}}$ \\
$80 \mathrm{~kg}$ & $96.9^{\mathrm{a}}$ & $449.4^{\mathrm{a}}$ & $46.7^{\mathrm{a}}$ & $471.5^{\mathrm{a}}$ & $1478.4^{\mathrm{a}}$ & $0.304^{\mathrm{a}}$ \\
$120 \mathrm{~kg}$ & $96.3^{\mathrm{a}}$ & $417.7^{\mathrm{ab}}$ & $45.5^{\mathrm{a}}$ & $443.7^{\mathrm{a}}$ & $1324.2^{\mathrm{a}}$ & $0.338^{\mathrm{a}}$ \\
$160 \mathrm{~kg}$ & $96.3^{\mathrm{a}}$ & $356.9^{\mathrm{b}}$ & $45.3^{\mathrm{a}}$ & $449.5^{\mathrm{a}}$ & $1376.3^{\mathrm{a}}$ & $0.305^{\mathrm{a}}$ \\
\hline
\end{tabular}

Means within the same letter(s) at each column were not significant differences at 0.05 probability level. PH: plant height, S/m²: spike per square meter, GY: grain yield, KW: 1000-kernel weight, TDM: total dry matter, HI: harvest index. 
Table 7. Mean comparison triticale traits at different clipping stages and nitrogen applications.

\begin{tabular}{|c|c|c|c|c|c|}
\hline Clipping stage & Nitrogen level (kg/ha) & GS & CPF (\%) & OMF (\%) & EP (\$/ha) \\
\hline \multirow{5}{*}{ Non-clipping } & Control & $56^{\mathrm{ab}}$ & $2.0^{\mathrm{f}}$ & $98.9^{\mathrm{a}}$ & $3674.7^{\mathrm{ab}}$ \\
\hline & 40 & $60^{\mathrm{a}}$ & $2.6^{\mathrm{df}}$ & $98.8^{\mathrm{a}}$ & $3324.1^{\mathrm{bc}}$ \\
\hline & 80 & $49^{\mathrm{ac}}$ & $4.8^{\mathrm{a}}$ & $67.9^{\text {cd }}$ & $3743.0^{\mathrm{a}}$ \\
\hline & 120 & $46^{\mathrm{ac}}$ & $2.4^{\mathrm{ef}}$ & $97.8^{\mathrm{d}}$ & $2886.0^{f}$ \\
\hline & 160 & $54^{\mathrm{ac}}$ & $2.0^{\mathrm{f}}$ & $97.8^{\mathrm{d}}$ & $3151.5^{\mathrm{ce}}$ \\
\hline \multirow{5}{*}{ Tiller stage } & Control & $59^{\mathrm{a}}$ & $2.7^{\mathrm{df}}$ & $97.8^{\mathrm{d}}$ & $3251.7^{\mathrm{bd}}$ \\
\hline & 40 & $40^{\mathrm{c}}$ & $2.4^{\mathrm{ef}}$ & $97.8^{\mathrm{a}}$ & $2908.1^{f}$ \\
\hline & 80 & $42^{\mathrm{bc}}$ & $4.0^{\mathrm{b}}$ & $98.0^{\mathrm{bd}}$ & $3090.4^{\text {de }}$ \\
\hline & 120 & $59^{\mathrm{a}}$ & $2.6^{\mathrm{df}}$ & $98.6^{\mathrm{ac}}$ & $3336.5^{\mathrm{b}}$ \\
\hline & 160 & $51^{\mathrm{ac}}$ & $3.2^{\mathrm{cd}}$ & $98.9^{\mathrm{a}}$ & $3038.7^{\mathrm{ef}}$ \\
\hline \multirow{5}{*}{ Booting stage } & Control & $41^{\mathrm{c}}$ & $2.2^{\mathrm{f}}$ & $98.6^{\mathrm{ab}}$ & $2553.3^{\mathrm{g}}$ \\
\hline & 40 & $44^{\mathrm{bc}}$ & $2.3^{\mathrm{f}}$ & $98.0^{\mathrm{ab}}$ & $2606.9^{9}$ \\
\hline & 80 & $47^{\mathrm{ac}}$ & $3.1^{\mathrm{de}}$ & $98.1^{\text {bd }}$ & $3305.2^{\mathrm{bc}}$ \\
\hline & 120 & $42^{\mathrm{bc}}$ & $2.4^{\mathrm{ef}}$ & $99.1^{\mathrm{a}}$ & $2651.1^{\mathrm{g}}$ \\
\hline & 160 & $47^{\mathrm{ac}}$ & $3.9^{\mathrm{bc}}$ & $99.0^{\mathrm{a}}$ & $2501.1^{\mathrm{g}}$ \\
\hline
\end{tabular}

Means within the same letter(s) at each column were not significant differences at 0.05 probability level. GS: grain per spike, EP: economical proficiency, OMF: organic matter of forage, CPF: crude protein of forage.

ping at booting stage with $1070 \mathrm{~g} / \mathrm{m}^{2}$ had the most and lowest total matters, respectively (Table 5). The highest plant height at non-clipping stage with $110 \mathrm{~cm}$ and the lowest plant height at clipping in booting stage with 75 $\mathrm{cm}$ were achieved. With delaying clipping vegetative growth reduced and consequently dwarfed plant height. Researchers stated that clipping at different stages of growth in cereal such as wheat and barley reduce $10 \%$ plant height [9] [13].

Forage quality: The most organic matter of forage with 99.1\% was in clipping at booting stage and $120 \mathrm{~kg} / \mathrm{ha}$ nitrogen fertilizer application, clipping at tiller stage and $160 \mathrm{~kg} / \mathrm{ha}$ nitrogen fertilizer application with 98.9\%, non-clipping and no nitrogen fertilizer application with $98.9 \%$. In contrast the lowest organic matter of forage was clipping at tiller stage no nitrogen fertilizer application and non-clipping and $120 \mathrm{~kg} / \mathrm{ha}$ nitrogen fertilizer application with 97.8\% (Table 7). Similar results have also obtained by various researchers in oat and barley [14].

The most crude protein of forage in non-clipping and $80 \mathrm{~kg} / \mathrm{ha}$ nitrogen fertilizer application with $4.8 \%$ and the lowest crude protein in clipping at booting stage and $40 \mathrm{~kg} / \mathrm{ha}$ nitrogen fertilizer application, clipping at booting stage and no nitrogen fertilizer application, non-clipping and $160 \mathrm{~kg} / \mathrm{ha}$ nitrogen fertilizer application and non-clipping and no nitrogen fertilizer application with less than $2.3 \%$ were achieved.

Economical proficiency: In order to determine the best clipping forage with nitrogen fertilizer amount of economical values were calculated (Table 8). The most economical proficiency of forage consumption was in non-clipping and $80 \mathrm{~kg} / \mathrm{ha}$ nitrogen with 3743.4 \$/ha so that to achieve maximum economic value of triticale is used for the single purpose also at this stage had the highest profit grain yield.

If triticale was used as dual purpose, the best time for harvest forage was tiller stage with $120 \mathrm{~kg} / \mathrm{ha} \mathrm{nitrogen}$ fertilizer and had 3336.5 \$/ha income. In contrast, the minimum economic efficiency allocated at clipping in booting stage and consumption of $160 \mathrm{~kg} /$ ha nitrogen fertilizer with 2501.1 \$/ha. It wasn’t recommended clipping of forage at booting stage. Reduction in economic efficiency of clipping at booting stage was due to reduce grain yield and despite the higher production, reduction in the income can be observed moreover clipping at booting stage reduced $50 \%$ straw yield in comparison clipping at tiller stage.

Relationships of traits: Economical proficiency was positively correlated with spike per square meter $\left(0.87^{* *}\right)$, 
grain yield $\left(0.64^{* *}\right)$, total wet mater $\left(0.65^{* *}\right)$, plant height $\left(0.52^{*}\right)$, 1000-kernel weight $\left(0.54^{*}\right)$ (Table 9). With increasing each of them farming was profitable.

To estimate the economic value of the grain yield, straw and total dry matter was used to stepwise regression where the economic value as the dependent variable and grain yield, straw and total matter as the independent variable were in the model (Table 10).

Table 8. Economical proficiency of triticale production in Saatlo station during 2012-2013 (prices are based on USD/ha).

\begin{tabular}{|c|c|c|c|c|c|c|c|c|c|c|}
\hline \multirow{2}{*}{$\begin{array}{l}\text { Clipping } \\
\text { stage }\end{array}$} & \multirow{2}{*}{$\begin{array}{l}\text { Nitrogen level } \\
(\mathrm{kg} / \mathrm{ha})\end{array}$} & \multicolumn{5}{|c|}{ Input } & \multicolumn{3}{|c|}{ Output } & \multirow{2}{*}{ Proficiency } \\
\hline & & Land preparation & Sowing & $\begin{array}{l}\text { Agronomical } \\
\text { practices }\end{array}$ & Harvest & Etc. & Grain & Staff & Forage & \\
\hline \multirow{5}{*}{$\begin{array}{l}\text { Non } \\
\text { clipping }\end{array}$} & Control & 58 & 103 & 166.5 & 82.0 & 238.5 & 2031.7 & 2291.0 & 0 & $3674.7^{\mathrm{ab}}$ \\
\hline & 40 & 58 & 103 & 169.7 & 82.0 & 238.5 & 1855.1 & 2120.4 & 0 & $3324.1^{\mathrm{bc}}$ \\
\hline & 80 & 58 & 103 & 172.9 & 82.0 & 238.5 & 2071.5 & 2326.0 & 0 & $3743.0^{\mathrm{a}}$ \\
\hline & 120 & 58 & 103 & 176.2 & 82.0 & 238.5 & 1876.8 & 1666.8 & 0 & $2886.0^{f}$ \\
\hline & 160 & 58 & 103 & 179.4 & 82.0 & 238.5 & 1833.5 & 1978.9 & 0 & $3151.5^{\text {ce }}$ \\
\hline \multirow{5}{*}{$\begin{array}{l}\text { Tiller } \\
\text { stage }\end{array}$} & Control & 58 & 103 & 166.5 & 102.5 & 238.5 & 1610.0 & 1862.3 & 448.0 & $3251.7^{\mathrm{bd}}$ \\
\hline & 40 & 58 & 103 & 169.7 & 102.5 & 238.5 & 1557.5 & 1642.6 & 397.7 & $2908.1^{\mathrm{f}}$ \\
\hline & 80 & 58 & 103 & 172.9 & 102.5 & 238.5 & 1642.8 & 1693.1 & 429.5 & $3090.4^{\text {de }}$ \\
\hline & 120 & 58 & 103 & 176.2 & 102.5 & 238.5 & 1717.1 & 1895.8 & 401.7 & $3336.5^{\mathrm{b}}$ \\
\hline & 160 & 58 & 103 & 179.4 & 102.5 & 238.5 & 1347.5 & 1978.9 & 393.7 & $3038.7^{\mathrm{ef}}$ \\
\hline \multirow{5}{*}{$\begin{array}{l}\text { Booting } \\
\text { stage }\end{array}$} & Control & 58 & 103 & 166.5 & 98.4 & 238.5 & 586.9 & 886.6 & 1744.1 & $2553.3^{g}$ \\
\hline & 40 & 58 & 103 & 169.7 & 98.4 & 238.5 & 575.2 & 842.9 & 1856.4 & $2606.9^{g}$ \\
\hline & 80 & 58 & 103 & 172.9 & 98.4 & 238.5 & 741.5 & 1087.9 & 2146.7 & $3305.2^{\mathrm{bc}}$ \\
\hline & 120 & 58 & 103 & 176.2 & 98.4 & 238.5 & 678.4 & 1087.9 & 1558.9 & $2651.1^{\mathrm{g}}$ \\
\hline & 160 & 58 & 103 & 179.4 & 98.4 & 238.5 & 598.7 & 877.9 & 1701.8 & $2501.1^{\mathrm{g}}$ \\
\hline
\end{tabular}

Means within the same letter(s) at each column were not significant differences at 0.05 probability level.

Table 9. Simple correlation coefficient of triticale traits under different clipping stages and nitrogen fertilizers.

\begin{tabular}{|c|c|c|c|c|c|c|c|c|c|}
\hline Trait & $\mathrm{S} / \mathrm{m}^{2}$ & GS & KW (gr) & HI (\%) & $\mathrm{GY}\left(\mathrm{gr} / \mathrm{m}^{2}\right)$ & $\mathrm{TDM}\left(\mathrm{gr} / \mathrm{m}^{2}\right)$ & EP (\$/ha) & CPF (\%) & OMF (\%) \\
\hline $\mathrm{PH}(\mathrm{cm})$ & $0.59^{*}$ & $0.64^{* *}$ & $0.91^{* *}$ & -0.33 & $0.97^{* *}$ & $0.94^{* *}$ & $0.51^{*}$ & -0.08 & 0.16 \\
\hline $\mathrm{S} / \mathrm{m}^{2}$ & & 0.45 & $0.66^{* *}$ & -0.51 & $0.69^{* *}$ & $0.68^{* *}$ & $0.87^{* *}$ & -0.16 & -0.32 \\
\hline GS & & & $0.68^{* *}$ & -0.09 & $0.58^{*}$ & $0.66^{* *}$ & 0.38 & -0.02 & 0.24 \\
\hline KW (gr) & & & & -0.34 & $0.91^{* *}$ & $0.89^{* *}$ & $0.54^{*}$ & -0.12 & 0.16 \\
\hline HI (\%) & & & & & -0.38 & -0.39 & -0.30 & 0.41 & 0.30 \\
\hline $\mathrm{GY}\left(\mathrm{gr} / \mathrm{m}^{2}\right)$ & & & & & & $0.95^{* *}$ & $0.64^{* *}$ & -0.11 & 0.10 \\
\hline $\operatorname{TDM}\left(\mathrm{gr} / \mathrm{m}^{2}\right)$ & & & & & & & $0.64^{* *}$ & 0.02 & -0.01 \\
\hline $\mathrm{EP}(\$ / \mathrm{ha})$ & & & & & & & & -0.13 & -0.22 \\
\hline CPF (\%) & & & & & & & & & -0.16 \\
\hline
\end{tabular}

${ }^{*}$ and ${ }^{* *}$ : were significant at 0.05 and 0.01 probability levels, respectively. PH: plant height, GS: grain per spike, S/m²: spike per square meter, GY: grain yield, KW: 1000-kernel weight, TDM: total dry matter, HI: harvest index, EP: economical proficiency, OMF: organic matter of forage, CPF: crude protein of forage. 
Table 10. Regression coefficients of related traits with economical proficiency of triticale.

\begin{tabular}{ccccc}
\hline Model & Standardized coefficients & Un-standardized coefficients & Standard deviation error & Probability level \\
\hline Constant & - & -1676.61 & 83.77 & 0.00 \\
Straw & 1.35 & 0.99 & 0.015 & 0.00 \\
Total dry matter & 2.10 & 1.01 & 0.013 & 0.00 \\
Grain yield & 1.53 & 1.03 & 0.020 & 0.00 \\
\hline
\end{tabular}

$\mathrm{R}^{2}=0.99$.

Economic value $(\$)=$ straw $(\mathrm{gr})(0.99)+$ total dry matter $\left(\mathrm{gr} / \mathrm{m}^{2}\right)(1.01)+$ grain yield $\left(\mathrm{gr} / \mathrm{m}^{2}\right)(1.03)-$ 1676.61 .

The model was significant at 0.01 probability level. By using three traits, straw, total dry matter and grain yield, economic value can be predicted.

\section{Conclusion}

Most economic benefit of triticale cultivation was achieved on non-clipping with $80 \mathrm{~kg} / \mathrm{ha}$ nitrogen fertilizer application. If the purposes are monetary benefit strictly or dual cultivation for using forage and grain, recommended harvested during growing season with $80 \mathrm{~kg} / \mathrm{ha}$ tillering stage and $120 \mathrm{~kg} / \mathrm{ha}$ nitrogen fertilizer applications, respectively. In order to increase the grain yield of triticale in breeding programs that have the greatest impact of coefficient on the economic value, from plant height, spike per square meter and 1000-kernel weight as the indirect measures economic value can be increased to improve the performance and utilize ultimately.

\section{References}

[1] FAO (2012) Year Book Production. Rome, 129.

[2] Skorda, E. (1977) Effect of Clipping on Forage and Grain Production from Barley, Wheat and Triticale. ICARDA, Aleppo, 266-274.

[3] Friedrich, H.P. (1993) The Properties of Triticale as Bulk Material. Muhlr-Misch Futter Technik, 130, $280-281$.

[4] Baier, A.C., Gustafson, J.P., Guedes Pinto, H., Darvey, N. and Carnide, V.P. (1996) Triticale: Today and Tomorrow. Kluwer Academic Publishers, Berlin, 563-567. http://dx.doi.org/10.1007/978-94-009-0329-6_71

[5] Freer, M.J., Donnlly, R., Axelsen, A., Davidson, L.F. and Dymocke, J. (1997) Comparison of Secale Wheat with Other Perennial Grasses under Grazing at a Cool Site in the High Rainfall Zone of New South Wales. Australian Journal of Experimental Agriculture, 37, 19-25. http://dx.doi.org/10.1071/EA96062

[6] Sprague, M.A. (1997) The Effects of Grazing Management on Forage and Grain Production from Rye, Wheat and Oats. Agronomy Journal, 46, 29-33. http://dx.doi.org/10.2134/agronj1954.00021962004600010009x

[7] Conver, M.R. (1988) Effect of Grazing by Canada Geese on Winter Growth of Rye. Spird, 3, 30.

[8] Christiansen, S., Svejcar, T. and Phillips, W.A. (1989) Spring and Fall Cattle Grazing Effects on Components and Total Grain Yield of Winter Wheat. Agronomy Journal, 81, 145-150. http://dx.doi.org/10.2134/agronj1989.00021962008100020002x

[9] Pumpherey, F.V. (2000) Semi Dwarf Winter Wheat Response to Early Spring Clipping and Grazing. Agronomy Journal, 62, 641-643. http://dx.doi.org/10.2134/agronj1970.00021962006200050028x

[10] Miller, G.L., Joost, R.E. and Harrison, S.A. (1993) Forage and Grain Yields of Wheat and Triticale as Affected by Forage Management Practices. Crop Science, 33, 1070-1075. http://dx.doi.org/10.2135/cropsci1993.0011183X003300050039x

[11] Andrews, C.J., Seaman, W.L. and Pomeroy, M.K. (1984) Changes in Cold Hardiness, Ice Tolerance and Total Carbohydrates of Winter Wheat under Various Cutting Regimes. Field Crops Abstract, 38, 221.

[12] Sharrow, S.H. (2003) Defoliation Effects on Biomass Yield Components of Winter Wheat. Canadian Journal of Plant Science, 70, 1191-1194. http://dx.doi.org/10.4141/cjps90-146

[13] Day, A.D., Thompson, R.K. and McGoghey, W.F. (1998) Effect of Clipping on the Performance of Spring Barley 
Seeding in October. Agronomy Journal, 60, 11-12. http://dx.doi.org/10.2134/agronj1968.00021962006000010004x

[14] Droushiotis, D.N. (2001) Effect of Grazing Simulation on Forage Hay and Grain Yields of Spring Barleys in a Low Rainfall Environment. Journal of Agricultural Science, 103, 587-594. http://dx.doi.org/10.1017/S0021859600043719 
Scientific Research Publishing (SCIRP) is one of the largest Open Access journal publishers. It is currently publishing more than 200 open access, online, peer-reviewed journals covering a wide range of academic disciplines. SCIRP serves the worldwide academic communities and contributes to the progress and application of science with its publication.

Other selected journals from SCIRP are listed as below. Submit your manuscript to us via either submit@scirp.org or Online Submission Portal.
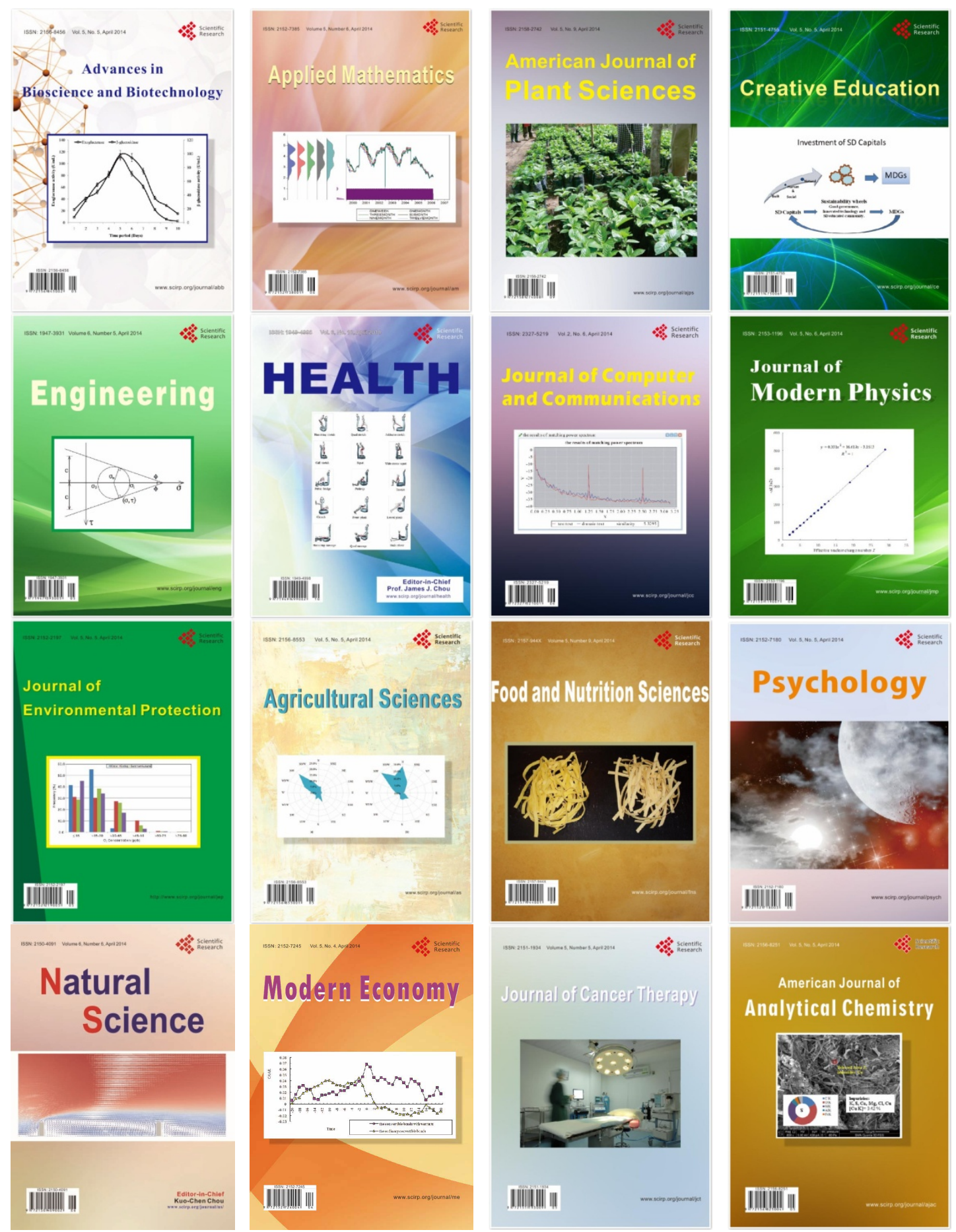